\title{
A Critical Review on Reducing Human Error
}

\author{
Elisabet Siahaan \\ Management Department, Faculty of Economic and Business \\ University of Sumatera Utara \\ Medan, Indonesia \\ Dr.Elisabethsiahaan13@gmail.com
}

\begin{abstract}
In nowadays competition, a private hospital services could be categorized as monopolistic competition. Many of new private hospital established were increasing in the current competition. In order to win, survive in competition, one had to offer a better performance, better competitive advantage from the others. As we spoke of services, one of critical point to build the advantage was through human assets management while reducing human error. A less likely error in services industries would generate a better performance and perceive value from the customer. The source of patients' compliance commonly occurred due to human error, especially the paramedic team. Therefore, we maximized hospital's human assets management to reduce error while preventing it happen in the future. This study aimed to evaluate the human assets management process to reduce human error on private medical field. A number of 138 paramedics of private hospital in Medan were involved in this study. Data were collected by using an organized questionnaire. Data were analyzed using multiple linear regression with SPSS. As result, we found that naturally, human factor tended to create an error while working. These level of error could be reduced overtime through an effective recruitment process and developing employees' skill related to their job. The most important factor to be considered was training and development as it would greatly reduce the human error. This study explained $40.4 \%$ variance of human error through selection, and training and development process.
\end{abstract}

Keywords: Human Error, Selection, Employee Training

\section{RESEARCH BACKGROUND}

The development of technology nowadays has increased properly. There are many industrial processes which can be solved automatically. However, no matter how sophisticated a system or a technology itself, there is always human's intervention needed within the process. At least, human is needed in the machine services or procedure implementation of that system. Production factor from human resources point of view is a very important factor. But, there is one thing to be understood is that human's intervention within the process does not always give the best result. Sometimes human makes mistake in his or her work. For example, someone may fail in doing the job procedure or may not understand the situation happened because of lack of carefulness, experience, and skill.

Human error is a part of humanity. Almost every job field cannot be apart from human error. The impact of human error itself will cause a serious negative effect on an individual, a team, and a company such as small accident, temporer disability, permanent disability, even death and psychological problem. That is why, a research on human error is really needed, so the causal factor and the prevention can be known and anaylised to minimalize the human error itself to be happened.

Human error is defined as a decision or human's behaviour which is wrongly done as it can reduce the effectivity, the safety, or even the performance system (Sanders and McCormick, 2010). Human error can happen in every type of jobs. In medical environment, an error done at the work may end as a fatal thing. The purpose of the medical services given by the hospital is tot ake care and to cure the physical and mental condition of the patient. Meanwhile, human error causes the opposite, the patient will go home lately, his or her psychological condition will be disturbed, will face a temporer or permanent disability, even the death. As an example, giving wrong 
medicines to patient can decrease his or her health condition. Being imprudent in changing the empty oxygen tube can also be dangerous for the patient's life.Commonly, the imprudence's happened because of human error seem like minor things and do not need further solution. However, there are some types of errors which can cause disability, or even put the patient's life into danger (Rooney et al 2002). A fatal error will bring a conflict and a claim from the patient. Patient can claim the hospital at any time for the illegal practical of the errors done by the hospital. This kind of situation must be avoided.

Human error happened in a hospital must be avoided as possible as it can be, because the rise of that human error level will give a big negative impact, not only to the patient and the family, but also the hospital, the human error do-er and his or her profession. Beside a criminal complaint, it can be a civil complaint formed as a compensation. Then, the hospital will also face disadvantages continually and will end with a permission retraction and a closure of the hospital itself.

In Indonesia, the level of medical error happens is very variative from time to time. The level of medical error is between $2 \%$ until 89\% per year (Utarini, 2004).This kind of thing indicates the variatif situations of human error level happened in a hospital. Therefore, a good management will press the number of human errors happened.

Human error in hospital environment commonly happens from paramedic side. UU No. 18, in 1964, the first point states that paramedic is a medical profession, usually a member of emergency medical services, who mainly serves an emergency treatment and a traumatic treatment. The potential of paramedics meant comes from medical Bachelor, in the middle and the lower, that is in the pharmacy field (pharmacist assistant and so on), in the midwifery field (midwife and so on), in the nursery field (nurse, physiotherapist, and so on), in the public health field (health observer, nutritionist, and so on), and the other healthcare fields (such as the part of laboratory or analyst)

Human error can also happen because of the error in the design and the work procedure (Peters, 2011). Beside that, human error can be also caused simply by three common things happened in a company, such as a particular thing goes to an individual (lack of training or education during the new personnel trial period) or a materialistic one (lack of management responsibility in setting the new personnel), and the other global things (financial pressure, time, and social or cultural application of the organization). From human resources management point of view, the selection process and the personnel training are the origin of human error itself. The improper selection process and the lack of socialization and training related to an imposed field to a paramedic can spark some errors in working.

RSIA Stella Maris in its selection process tries to press the operational cost so that it will select the potential of freshgraduated paramedic more, instead of the experienced one. Pay more attention to the physical condition, gender, and the appearance of the paramedic instead of the mental condition such as knowledge and skill. Fresh graduate recruitment is actually not a wrong thing, but it needs an effective selection system. Ineffective selection process makes the level of human error will increase soon. If the people work in unappropriated proficiency as needed, then the error tends to happen.

In line with the discussion about the manpower skill, the human resources management commonly will hold a personnel training periodically in order to make the personnel become more skillful in his or her field. The training process is the process which makes the personnel become more able to do his or her tasks. In the other hand, the obstacle in the training is about the financial and technical problems. Therefore, the training activity must be effective and efficient. Hopefully, through an effective training the human error level can be reduced. 
The paramedic training system in RSIA Stella Maris has ran well, but the training process is not that effective as some errors in working still happen, although the frequency gets lower, the training material is not enough suitable with the paramedic's needs. The personnel's mindset develops well, even though in an uneven proportion among the paramedics, so that it obtains an uneven working result. The purpose of this research is to know and to analyses the influence of selection and training against the level of human error done by a paramedic in RSIA Stella Maris Medan.

\section{THEORETICAL STUDY}

\section{Human Error}

A chance for an error to happen in paramedical action is caused by variability of the paramedical action itself. Although it is impossible if two paramedical actions are given the exact same handling (the characteristic of service variability (Kotler and Keller, 2013), a minor variability will not cause an error. But, at particular level this variability can be categorized as a human error.

Human error is a deviation from perfomance standard which has been determined before, so it causes a postponement as a result of difficulty, problem, incident, and failure (Peters, 2010). Human error is every action done by human which causes a deviation of standardization assigned by a system or procedure (Rooney et al, 2002). Human error can be categorized in two main groups. The first is unintentional error which is an action results an error without any intention to do so, such as pressing button accidentally, or getting forgetful in doing the machine service. The second is intentional error which is an error in action believed by the implementer as a right and the best action yet improper and risky in fact.

\section{Human Resources Selection}

Selection is a process in choosing and deciding the most suitable personnel candidate to be accepted as the personnel of a particular position (Hasibuan, 2008; Bangun, 2012; Suntoyo, 2012). The main purpose of selection process is to gain qualified manpower, whether it is from technical ability side, non-technical, interpersonal, development potential, and the company criteria.

Selection process is an application process of plan and working strategy for the human resources which has been set before. Selection process is the series of activity done by the human resources in choosing and deciding the most suitable personnel candidate according to the company needs. Selecting the qualified personnel who are suitable with the company needs and with the scheming of human resources is the purpose of selection process. A company which is able to select qualified personals will be more advanced and superior in a long term. The correct selection process makes the company feel the ease in doing the training. The company will be avoided from many problems. Therefore, selection decisions are a very important process, so they have to be based on objective thought and consideration.

A good selection process must have some characteristics (Sofyandi, 2008) as follow.

1. Standardization, a good test must have uneven procedure and condition for all participants.

2. Objectivity, for every similar answer must be given a result or value test, not based on the subjectivity against particular aspects of the test participants.

3. Norm, every test must have norm, that is a reference framework to compare the applicants' achievements. Without norm, the result of a participant cannot be classified: whether the value is good or bad, whether he or she passes or not, 
whether the value is better or worse than the other participants.

4. Reliability, it means that a selection device (usually a test) gives a consistent result everytime someone takes this test.

5. Validity, it means that the selection device (usually a test) is significantly connected to the working achievement or another relevant criteria. In other words, a test is said to be valid if it correctly values what it actually wants.

\section{Personnel Training}

Training is a very important activity whether for the personnel or the company. Training is a programme expected to give a stimulus to someone in improving the ability of any particular job, getting a general knowledge and an understanding to the whole work and organization environment (Sofyandi, 2008). Training is a process which teaches the new personnel or current personnel about the basic skills that they need to do their work (Dessler, 2011).

As the outline, there are some things which can be a benchmark for the success of a training programme. Sullivan (2005) stated the basics in measuring the training effectivity as follow.

1.Training programme implementation monitoring

In this phase, the company will hold a supervision and a research about the training implementation by looking at:

a. The enthuasism level of personnel during the training programme

b. The liveliness of personnel during the training programme

c. The ability of training instructor in delivering the material

$d$. The content of the material which is suitable with the training needs

\section{Training effectivity monitoring}

In a training implementation, not all personnel's will be able immediately to practice the training material given earlier. It is predicted that there is a particular grace period between the expected change from the company and the end of training span. So, the duty of the company is to measure:

a. whether there is a behavior change after following the training

b. the ability of personnel in removing errors

c. how long the positive change of personnel after the training is

d. the improvement of knowledge, ability, and behaviour of personnel

e. the formation of personnel's mindset

f. the improvement of personnel's work result after the training implementation

\section{Conceptual Framework and Hypothesis}

Evyta (2016), Hamadini (2012), Rahmiyanti (2012), Nainggolan (2011), Cahaya (2011), Lee (2011) Rohimah (2010) stated that a correct and objective section process which is based on the needs and the human resources plan will be able to get a good and qualified personnel. This decision will make the company to be able reach a success for a long term.

Sukadarma (2015),Menap (2015), Yulia (2013), Suheni (2013) stated that an effective training based on the work measurement process and the paramedic's needs will improve the way in finishing the duties, so that the human error will decrease.

Based on the theoritical study stated and the problem phenomenon, the conceptual framework in the reasearch is submitted as follow.

Source: Peters (2011), Ismail (2010), and Simanjuntak (2005).

Figure 1. Research Conceptual Framework 
By concerning the conceptual framework (Figure 1), the hypothesis given for this research is as follow.

$\mathrm{H}_{1}$ : The selection effectivity significantly gives a negative impact to the human error level done by the paramedic in hospital environment

$\mathrm{H}_{2}$ : The paramedic's training effectivity significantly gives a negative impact to the human error level done by the paramedic in hospital environment

\section{RESEARCH METHODS}

\section{Location and Time of the Research}

The research was conducted in RSIA Stella Maris, which is located at Jl. Samanhudi No. 20 Medan. The research was started from January 2016 until May 2016.

\section{Research Sample}

The population in this research was 211 persons of paramedics at RSIA Stella Maris which consisted of nurse, midwife, pharmacist, and laboratory expert. The number of the sample needed in this research was calculated by using the slovin formula with $5 \%$ tolerance. The number of sample in this research was 138 paramedics. Sample in this research was taken randomly based on the list of current employees. The number of sample from each group was taken proportionally.

\section{Data Collection Method}

The data was collected by using the structural questionnaire which was given to the hospital. The questionnaire was set based on the suitable theoritical study in measuring the research variable. The questionnaire used 7-point Likert scale which was suitable to measure respondent's perception from the questions given. The respondent's participation level in this research reached
$100 \%$ from 138 questionnaires distributed to the hospital.

\section{Data Analysis Method}

The data obtained was analysed by using the multiple regression method. The dependent variable in this research was human error perception happened among the paramedics. The independent variable in this research was the perception of selection system effectivity and training effectivity which was perceived by the paramedics. The data was analysed descriptively and inferentially to understand the actual thing happened in the field and to predict the influence between variables.

\section{RESULTS AND DISCUSSION}

\section{Respondent's Characteristic}

The majority of respondents in this research was aged 20-30 years old. There were 106 persons (76,8\%). All respondents were female and there were 138 persons $(100 \%)$, because it is a hospital for mother and child. The majority of respondents had the last education as Academic/Diploma, and there were 112 person $(81,2 \%)$.

\section{The Descriptive Statistic Summary of the} Research

Based on the respondents' answers that the selection process had ran really well, because the employee was accepted to work if he or she fulfilled the educational criteria, that was Academic/Diploma, and a good physical condition criteria so that he or she would be avoided from a frequent absence caused by a sickness. Based on the skill criteria such as technical skills, conceptual skills, and soft skills. The selection process also considered the work experience especially in midwifery and nursery divisions which required the paramadics to have a minimal 11 years of experience. 


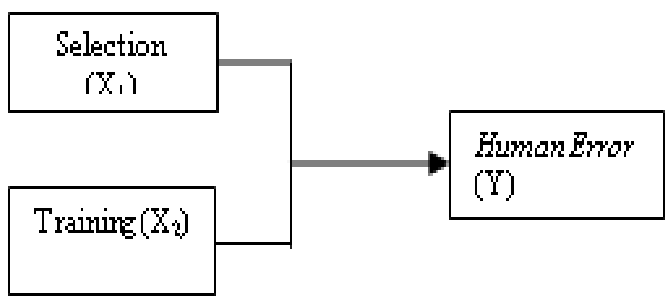

Based on the respondents' answers that trainings held had a huge benefit. A training followed by the paramedics were able to change their mindset and behaviour after it. In this case, after following the training programme the participants became more spiritful in working. They also became more able to control the emotion while facing a problem so that the errors which might happen could be minimalized as well as possible.

Based on the respondents' answers, human error level in that hospital was really low. That thing could be seen from the low average of ignoring the Standard Operating Procedure (SOP). The paramedics in that hospital had always done the SOP which consisted of SOP for diagnostic, SOP for laboratory technical examination, SOP for nursery standard, and SOP for patient's operation preparation.

\subsection{The Examination of Hypothesis}

Table 1 Goodness of Fit Model Summary

\begin{tabular}{|l|c|r|r|}
\hline Model & $\mathrm{R}$ & $\mathrm{R}$ Square & Adjusted R Square \\
\hline 1 & $.642^{\mathrm{a}}$ & .413 & .404 \\
\hline
\end{tabular}

a. Predictors: (Constant), Training, Selection

b. Dependent Variable: Human Error

Table 1 shows $\mathrm{R}=0,642$ means that Selection and Training are deeply correlated to the level of Human Error for 64,2\%. Adjusted $R$ Square valued as 0,404 means 40,4\% Human Error factorscan be explained by Selection dan Training. While the rest of $59,6 \%$ can be explained by the other factors which are not discussed in this research.
Table 2 Simultaneous Effect of Employees' Selection and Training

\begin{tabular}{|l|l|c|c|}
\hline \multicolumn{2}{|l|}{ Model } & F & Sig. \\
\hline 1 & Regression & 47.425 & $.000^{\mathrm{b}}$ \\
\hline
\end{tabular}

Dependent Variable: Human Error Predictors: (Constant), Training, Selection Table 2 showsthat Selection $\left(\mathrm{X}_{1}\right)$ variabledan Training $\left(\mathrm{X}_{2}\right)$ variable, simultaneously give positive impact and significance to Human $\operatorname{Error}(\mathrm{Y})$ variable.

Table 3 Multiple Regression Analysis Coefficients

\begin{tabular}{|c|c|c|c|c|c|}
\hline \multirow{2}{*}{\multicolumn{2}{|c|}{ Model }} & \multicolumn{2}{|c|}{ Coefficients } & \multirow[t]{2}{*}{$\mathrm{t}$} & \multirow[t]{2}{*}{ Sig. } \\
\hline & & $B$ & $\begin{array}{l}\text { Std. } \\
\text { Error }\end{array}$ & & \\
\hline \multirow{3}{*}{1} & (Constant) & 5.770 & .401 & 14.372 & .000 \\
\hline & Selection & -.276 & .110 & -2.516 & .013 \\
\hline & Training & -.409 & .126 & -3.243 & .001 \\
\hline
\end{tabular}

Dependent Variable: Human Error

Selection variable negatively and significantly affects the human error, and it is seen from the significance value $(0,024)$ lower than 0,05 and the value of $t_{\text {hitung(-2,291)< }}$ $t_{\text {tabel }}(1,657)$ means that if the selection variable increases as one unit, then the human error (Y) will decrease as 0,267 unit. The value of $t-$ negative shows that the selection variable has a different directional relation with human error and significant to human error.

Training variable negatively and significantly affects the human error, and it is seen from significance value $(0,010)$ lower than 0,05 and the value of $t_{\text {hitung }}(-2,605)<t_{\text {tabel }}$ $(1,657)$ means that if the training variable increases as one unit, then the human error (Y) will decrease as 0,389 unit. The value of $t-$ negative shows that training variable has a different directional relation with human error and significant to human error. 


\subsection{Discussion}

The selection process significantly affects the human error which means that if the selection process is ran in a better and more objective way, and also if it is suitable with the human resources plan, then the company will get a qualified employee. The paramedic accepted by the right selection process usually has a suitable scholarly background with what is needed, so his or her knowledge, skill, and behavior have been formed to reduce the level of human error. The management personnel who conducts the selection process correctly will get an employee who has understood the rules in medical field, in this point the employee has known which activity will be beneficial and harmful for the patient and the hospital. The management personnel who selects correctly will find an excellent characters and behaviors of paramedics such as physically and mentally healthy, diligent, friendly, careful, like to serve, clean, and discipline, so that the low human error level is expected.

The result of this research is parralel with the research of Evyta (2016), Harnadini (2012), Rahmiyanti (2012), Nainggolan (2011), Cahaya (2011), Lee (2011), and Rohimah (2010) which stated that a better and objective section process will bear a qualified work with low level human error.

Training negatively and significantly affects the human error. Paramedics are the vanguard in giving the health services, that is why the trained paramedics are needed to avoid and minimalize the human error. A periodic training, a training which is suitable with the paramedic's needs, a training based on the work evaluation result will be able to bear a work improvement. A training done to the paramedics will make them master the right and quick work completion method more, so that the behaviour and the way they work will be more proper. Training done to the paramedics is able to improve their ability in becoming skillful to finish their work, so that the work is done carefully, quickly, and the result will be qualified and far away from errors. The training will also improve the commitment in serving, form a powerful and superior characters of paramedics. The paramedics will be more willing in serving people with heart, with patience, and carefully to finish their work, so that the error level can be minimalized.

The result of this research was supported by Sukadarma (2015), Menap (2015), Yulia (2013), Suheni (2013), Ismail (2010) who stated that a training will improve the competence, the employee's knowledge, and the work behaviour, so the errors caused by the worker factor which may bring to a dangerous situation can be reduced.

\section{CONCLUSION}

Based on Uji-F, selection and training had positive and significant effect on human error. This meant that the better or the more objective a paramedic selection that were consist of general and special conditions, and the more frequent the training program for paramedics was hold, the human error percentage would be decreased in RSIA.Stella Maris, Medan. According to Uji-T, the training significantly gave the negative effect on human error of paramedicsst RSIA Stella Maris Medan. The more frequent the training programme that was suitable for the paramedics and the skillful training instructors, the more the knowledge, skill, and capability of the paramedics. This would make the paramedics and the training instructors smarter and more creative to face their daily works, so that the human error tragedies in that hospital could be decreased.

\section{FUTURE RESEARCH}

It is expected that the future researcher can develop this research in the near future through a deeper research by adding the other variables such as work pressure, work environment, leadership, double roles conflict, work satisfaction, motivation, and so on which can affect the human error of paramedics. 


\section{ACKNOWLEDGEMENT}

At this chance, the writer would like to say much gratitude to RSIA Stella Maris Medan which allowed the researchers to do this research. In the other hand, writer would also like to say much gratitude to the respondents of this research for giving their time and opinions.

\section{REFERENCES}

M.S., Sanders and E.J., McCormick, Human Factor in Engineering and Design, Seventh Edition, New York: McGrawHill Inc., 1993

J.J., Rooney, L.N., VandeenHeuvel, and D.K. Lorenzo, "Reduce Human Error: How to Analyze Near Misses And Sentinel Events, Determine Root Causes and Implement Corrective Action," Quality Progress, September 2002

A. Utarini, "Dokter pun Bisa Salah," Tempo Interaktiif, March 2011

Presiden Republik Indonesia, "Wajib Kerja Tenaga Paramedis," Undang-Undng No 18 Tahun 1964, Sekretaris Negara, Oktober 1964

G.A. Peters, Manajemen Mutu Pelayanan Kesehatan, Jakarta: Kedokteran EGC, 2011

P. Kotler and K.L. Keller, Marketing Management, 14th Edition. New Jersey: Prentice Hall, 2012

S.P. Hasibuan, Manajemen Sumber Daya Manusia, Jakarta: Bumi Aksara, 2008.

W. Bangun, Manajemen Sumber Daya Manusia, Jakarta: Erlangga, 2012

T.Y. Suwatno, Manajemen Sumber Daya Manusia, Bandung: Alfabeta, 2009

H. Sofyandi, Manajemen Sumber Daya Manusia, Edisi Pertama, Yogyakarta: Graha Ilmu, 2008

G. Dessler, Human Resource Management, 12th Edition, New York: Prentice Hall, 2011
J. Sullivan, "Measuring Training Effectiveness / Impact," Gately Consulting, April 1998

T. Rohimah, "Pengaruh Seleksi Calon Apoteker Terhadap Tingkat Pencegahan Medication Error Pada Rumah Sakit Ibu Dan Anak Citra Insani Parung Bogor," Skripsi, Universitas Pamulang, 2010

G.D. Cahaya, "Pengaruh Seleksi dan Penempatan Terhadap Prestasi Kerja Karyawan Dalam Menurunkan Tingkat Kesalahan Kerja Pada Rumah Sakit Muhammadiyah Gresik," Tesis, Universitas Muhammadiyah Gresik, 2011

S.C. Nainggolan, "Pengaruh Proses Rekrutmen Dan Seleksi Tenaga Kerja Keperawatan Dalam Peningkatan Mutu Pelayanan Keperawatan Guna Mencegah Kesalahan Medis Rumah Sakit Santa Elisabeth Medan," Skripsi, Universitas Indonesia, 2011

S. Harnadini, "Pengaruh Rekrutmen dan Seleksi Terhadap Tingkat Kesalahan Dalam Upaya Meminimasi Human Error (Studi Kasus Pada RS Tologorejo Semarang)," Skripsi, Universitas Diponegoro 2012

S. Yulia, "Pengaruh Pelatihan Keselamatan Pasien Terhadap Pemahaman Perawat Mengenai Penurunan Kesalahan Tindakan Medis di RS Tugu Ibu Depok," Skripsi, Universitas Indonesia, 2012

Suheni, "Pengaruh Pelatihan terhadap Medical Error pada Rumah Sakit Setia Mitra," Skripsi, Universitas Pamulang, 2013

Menap, Soedjajadi, and Nursalam, "Safetycare Training Effects on Nurses' Performance to Reduce Adverse Events at Hospital in Lombok, Indonesia," International Journal of Scientific and Research Publications, Volume 5, Issue 11, November 2015 